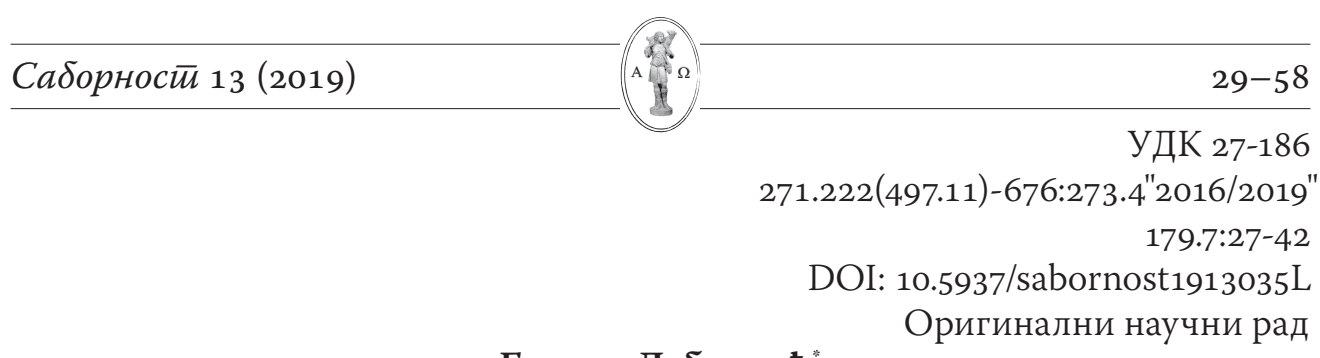

\title{
Богдан Лубардић"
}

Универзитет у Београду, Православни богословски факултет, Београд

\section{Хришћанско разумевање смрти и проблем еутаназије: допринос Међународне Комисије за англиканско- православни теолошки дијалог (ICAOTD): 2016-2019}

\begin{abstract}
: Аутор презентује рад Међународне комисије за англиканско-православни теолошки дијалог (ICAOTD) из друге, практичко-апликативне, фазе њеног ангажовања у пољу хришћанске антропологије. Из пет главних области питања што их у тој фази Комисија адресује, преко хришћански конципиране биоетике (ослоњене на договорена начела хришћанске антропологије), Комисија је прво издвојила два: питање еутаназије и питање природне средине. На основу увида у рад Комисије из периода 2016-2019, аутор излаже преглед основних доприноса изнетих током расправа о хришћанском схватању смрти у вези са проблемом еутаназије. Током пленарних дискусија о стручним саопштењима презентованим са обе стране (нарочито на скупу у Малти 2017), Комисија је поставила и руководна начела за оријентацију и вредновање поводом сложеног и осетљивог проблема еутаназије, и, поводом не сасвим сагледивих последица напретка биотехнологије и савремене науке. Поред осталог, Комисија је заузела становиште да феномен „еутаназије“ - уколико се колоквијално интерпретира као потпомогнуто самоубијање - треба пажљиво разликовати од приступа какав је потпомогнуто умирање (нпр. у смислу палијативне и хосписне неге, и слично), и, разликовати од етоса доброг умирања у хришћанском смислу, а на основу духовног расуђивања утемељеног разуђеним и целовитим црквеним схватањем умирања, смрти и смртности. У догледно време, Комисија ће усвојити Договорену изјаву о добром умирању, а поводом питања еутаназије.
\end{abstract}

Key words: Међународна Комисија за англиканско-православни теолошки дијалог (ICAOTD), хришћанска антропологија, начела и примене, биоетика, еутаназија, хришћанско схватање смрти и умирања.

P етроспективна и проспективна напомена. Радећи унутар четврте серије (фазе) разговора, званично започетих 1973. у Оксфорду, Међународна Комисија за англиканско-православни теолошки дијалог (ICAOTD; у даљем тексту: Комисија) испланирала је израду теолошког документа посвећеног и теоријским и практичким димензијама хришћанске антропологије. Тај документ има два де̂ла. У првом де̂лу, Према образу и

\footnotetext{
bogdanmiloslubardic@gmail.com
} 
3о | Лубардић, Б., Хришћанско разумевање смрйи и йроблем еуйаназије-

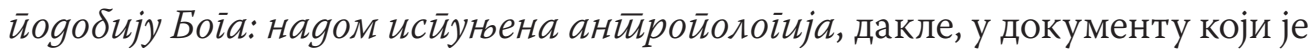
публикован као Бафало договорена изјава (САД 2015) ${ }^{1}$ - са ослонцем на персоналистички ${ }^{2}$ приступ - постављена су главна антрополошка учења заједничка нашим двема црквеним заједницама, англиканској и православној. У другом де̂лу, који је управо у фази нацрта кроз пленарне радне скупове Комисије као и њеног Руководно-редакционог одбора (Арма: Ирска 2016, Слиема: Малта 2017, Халки: Турска 2018, Ларнака: Кипар 2018; Кентербери: Енглеска 24. о6. 2019), и који треба да буде усвојен у будућностиз, преко више договорених изјава-декларација, Комисија намерава да назначи практичко-етичке консеквенце што следују из теолошких принципа утемељених у првом де̂лу, то јест у Бафало договореној изјави. Теме које се разматрају у текућој апликативној фази, а које чине главне предмете циљаних договорених изјава-декларација, укључују редом: (1) одговорност човечанства према природној околини (екологија), (2) људске интервенције у различитим етапама живота: (а) пре рођења (контрола рађања, абортус, експериментисање на фетусу, итд); (ठ) током живота (трансплантација органа, хормонске терапије, естетска хирургија и промена полног идентитета итд); и (в) у смрти (еутаназија: од потпомогнутог умирања до потпомогнутог самоубијања), (3) питања полности и сексуалности (полни идентитет, утицај политике и културе на разумевање улога и права полова), (4) смисао брака (специјално статус такозваних истополних заједница); а све наведене теме и питања укључују (5) наше схватање људских права. ${ }^{4}$

У раду презентујемо резултате рада Комисије на првом од два селектована проблема: наиме, резултате рада Комисије на давању адекватних одговора на горуће питање: еушианазија (други селектовани проблем, који Комисија тематизује паралелно првом, јесте горуће питање чувања природне средине од уништења: еколойлј). Једногласном одлуком Комисије, 20.10.2017. добили смо мандат да синтетишемо Нацрт предлога договорене изјаве 5 поводом проблема еутаназије. То смо учинили на основу научно-стручних радова које су у виду саопштења (током скупа на Малти: Слиема, 14-21.10.2017) износиле колеге из Комисије (Кларк, Роуланд-Џонс, Џојс, Хризостом китионски, Драгаш ${ }^{6}$ и Хемингс), уз пратеће интензивне дебате и разматрања.

1 ICAOTD, 2015.

2 BAS, стр. 9-21.

3 То се очекује или на следећем пленарном окупљању Комисије (Кентербери 10-17. октобар 2019) или на оном који ће последовати годину дана потом.

4 Лубардић, 2018, стр. 89-91.

5 План је да се по сваком од изабраних питања изради краћа Договорена изјава, респективно, и да се те изјаве затим саберу и објаве као други део, односно, као наставак Четврте договорене изјаве из Бафала 2015.

6 Осим свог гледишта о питању еутаназије, Георгије Дион Драгаш презентовао је и вредне теоријске материјале и радове Георгија Мандзаридиса, Јеротеја Влахоса и 
Захваљујући и групном раду на тексту (нарочито са Руководно-редакторским одбором Комисије у Турској: Халки, 19-20. 06. 2018.), Нацрт предлога смо презентовали на пленарном скупу у Ларнаки: Кипар 19.10.2018. Тај нацрт је усвојен као ваљана основа за даљи рад на поменутом питању. У међувремену, уз сарадњу са колегиницом са англиканске стране, Алисон Џојс (Alison Joyce), (после скупа у Ларнаки 2018, и током 2019. године, go састанка Одбора за припрему финалног нацрта у Кентерберију: Енглеска 24. 06. 2019.) продуковали смо, усаглашено, и другу верзију Нацрта предлога договорене изјаве о еутаназији и хришћанском разумевању смрти. Оно што следи јесте презентација досадашњих (синоптички интегрисаних) резултата рада Комисије за поменути период 2016-2019 и за поменуто питање: резултата из којих ће у своје време проистећи будућа декларација двеју Цркава о добром умирању, а поводом питања еутаназије. ${ }^{7}$

1. Увод: пред тајном смрти - између бола и наде. Смрт и процес умирања су неизбежне људске реалности, зато што смрт долази свима. С тим у вези, такође, дубоке су и мистерије којима ваља прићи смирено, пажљиво и са поштовањем. Расправљати о смрти захтева да поштено и бескомпромисно сагледамо људски бол и страдање, у свим облицима, укључујући најекстремније. Истовремено, ми смо збуњени чудним парадоксом: наиме, када се води мудро, саосећајно, и са бригом, процес смрти - умирања - може да произведе своје, можда неочекиване, а понекад упечатљиве дарове исцељења и наде, доносећи унутрашњи мир умирућем, и, излечење односа умирућег са живима. Та реалност је нешто што су озбиљно документовали практичари који раде унутар области секуларне палијативне ${ }^{8}$ неге, као и они који испраћају умируће унутар црквених оквира и уједно тумаче тај процес духовним очима вере. 9

Овај рад и резултати синтетисани у њему, који се гради на увидима из Договорене изјаве Комисије из 2015: Према образу и йоgoбију Боїа: наgом исииньена анйройолоїија = Image and Likeness of God: A Hope-Filled Anthropology, ${ }^{10}$ произашао је из разговора и узајамно размењиваних размишљања чланова Међународне комисије за Англиканско-Православни

Џона Брека, као и саопштења Посебног синодског одбора за биоетику Грчка православне цркве.

7 То се очекује или на следећем пленарном окупљању Комисије или на оном који ће последовати годину дана потом.

8 Према одређењу Међународне асоцијације за хосписну и палијативну негу, „Палијативна нега јесте холистичка брига за појединце свих старосних група који страдају од озбиљних патњи повезаних са тешким болестима, а нарочито за оне који су близу смрти. Она циља да побољша квалитет живота пацијената, њихових породица, и пружаоца услуга старања и бриге“. Видети: IAHРC, 2018.

9 Mannix, 2017; Joyce, 2017.

1 BAS, стр. 1-82. 
32 | Лубардић, Б., Хришћанско разумевање смрӣи и йроблем еуйаназије-

теолошки дијалог (ICAOTD) ${ }^{11}$. Англиканци и православни у различитим деловима света живе са неким од истих питања о смрти и умирању. Кроз заједнички рад истражили смо шта све делимо, као заједничко, у разумевању онога што означавамо изразом „умрети добро“ (dying well). У том процесу откривали смо широк консензус у многим областима. Међутим, установили смо и неке разлике у погледима и уверењима.

Сврха овог документа је да помогне у промишљању ове тешке људске реалности из перспективе хришћанске вере. Бавиће се и многобројним и контраверзним питањима у вези са потпомогнутим умирањем (assisted dying), и другим начинима на које завршетак живота може да се промени или контролише кроз људску интервенцију. Међутим, таква питања могу се ваљано разумети само у светлу дубљег истраживања природе људске смртности.

Треба имати на уму да процес умирања може веома различито да изгледа милионима оних у данашњем свету којима, рецимо, недостаје приступ чистој води за пиће, а да не говоримо о том искуству у случају располагања приступом префињеним облицима медицинских интервенција и третмана. Културолошке претпоставке о смрти, и обичајни модели понашања у вези са умирањем, могу се такође у великој мери разликовати. Постоје неке области дискурса ове расправе у којима секуларна медицинска мудрост и мудрост вере могу да пронађу заједнички терен. Постоје и друге области, оне у којима хришћанска вера доноси јединствене и себи својствене увиде. У односу на потпомогнуто умирање, такође постоји спектар позиција које заузимају људи добре воље и они саосећајни са обе стране дебате, који се упуштају у ово необично сложено и осетљиво питање у дискусији, чак и унутар заједнице верујућих.

У западним културама, поготово, смрт је последњи велики табу. На њу се упућује у таквим контекстима еуфемизама, који и сами сведоче о уздржаности да се отворено и поштено говори о смртности појединца. Та уздржаност може да одсликава духовно осиромашење друштва неспособног да призна, или се ухвати у коштац са фундаменталном истином да је човек смртан ${ }^{\mathbf{1 2}}$. Смрт и умирање су увелико скривени и њима се професионално „управља“ у западним културама. То веома ограничава изложеност већине људи стварности смрти, што може заузврат да спречи праву информисаност учесника у јавној раправи. ${ }^{\mathbf{1 3}}$

Рођење и смрт се често постављају контрастно као супротни екстреми: прво је повезано са надом, радошћу и оптимизмом у обећани нови живот; а последње се узима као изолација, губитак и чак очајавање. Ипак,

11 Списак чланова и црквених тела која они представљају за период 20о9-2015 видети:

BAS, стр. 83-88. Списак садашњих чланова видети: Прилог.

12 BAS, стр. 47-49.

13 Jones, 2017. 
дубље и целовитије разумевање процеса умирања позива да истражимо њихове сличности, као и њихове разлике. Речју, умирати добро део је тога да живимо добро.

2. Библијски и теолошки погледи на смрт и умирање. Упоредо са интристичним ауторитетом Библије за све хришћане, мудрост Библије у погледу смрти и умирања, и њен ангажман са тако суровом, а често сложеном стварношћу људског страдања, обухвата увиде који су и даље од трајног значаја. Јудео-хришћанска традиција истиче да је људска бића створио Бог, и то за вечни живот са Богом. Према наративу о стварању у Књизи Постања (Пост 2, 3), смрт нема место у Божијој првобитној намери, већ уместо тога представља погубни поремећај у вези са првобитном Божијом намером за човека, настао као последица пада Пост 3, 19). У нашем урођеном нагону за опстанком и чежњи за Богом, која је карактерисала људско срце током историје, можда одјекује наш осећај да смо изгубили живот за који смо првобитно створени. Као што је Свети Августин Хипонски приметио: „Створио си нас за себе, Боже, и наша срца су неспокојна док не пронађу починак у Теби“ ${ }^{14}$

Управо на основу тога, Христова победа над смрћу и откривење његове спаситељске силе, добијају пуни смисао и значај, како то снажно проповеда Свети Павле у својим Посланицама: Христова победа над смрћу је победа над „последњим непријатељем“ (1Кор 15, 26). Та победа отвара пут ка вечном животу у слави са Богом.

Болест и смрт, стварности које карактеришу људски живот у садашњем свету, у Светом Писму су представљени као зла којима се треба одупрети и која треба превазићи. Књига о Јову је проширено промишљање о збуњујућој и разорној стварности незаслужене патње. У Новом Завету, спасоносна Христова снага види се у његовом исцељивању болесних и у подизању из мртвих Лазара (Јн 11, 43-44) и Јаирове кћери (Мк 5, 41; Мт 9, 18-26; Лк 8, 40-56). Сва таква чуда пружају земаљски предукус живота са Богом који нема краја: живота који је постао доступан, парадоксално, Христовом спаситељском смрћу.

Истовремено, посматрано из контекста нашег садашњег живота, процеси смрти и умирања се, очекивано, схватају као природни и неизбежни. То су теме којима ћемо се вратити.

У своме страдању и смрти, Исус Христос је доживео потпуни ужас незаслужене људске патње, у највећој мери бесмислене и варварске. У неким од извештаја Светог Писма видимо његову забринутост у Гетсиманском врту због искушења пред којим стоји, када Оца моли овако: „пронеси чашу ову мимо мене“ (Мк 14, 36). Видимо његов осећај тоталне остављености и потребу за заједничарењем (кад буди своје ученике, говори Петру:

14 Sancti Aureli Augustini, Confessiones, I:1, Migne, PL 32, стр. 661. 
„Симоне! Зар спаваш? Не може ли једнога часа постражити?“” (Мк 14, 37). И чујемо његов крик што тражи изузимање од крста: крајњу изјаву мучне боли, пустоши и страха од напуштања (Мк 15, 34; Мт 27, 46). Па ипак, уткани око ових тема, пратећи су мотиви Христове постојане верности и делатно-драговољног прихватања своје судঠе („али опет не како ја хоћу, него како ти“, Мк 14, 36), што је кулминирало његовом свесном предајом свога живота Богу, да би Божије дело могло да буде завршено његовом спасоносном смрћу (Jн 19, 30). Он остаје „у свему кушан као и ми, али без греха“" (Јевр 4, 15; 1Пет 1, 19). Међутим, важно је да Нови Завет са пуном озбиљношћу схвата тамну стварност патње и смрти и непрестано се ठави тим темама.

Са парадигмом распетог Спаситеља пред собом, као одређено изненађење за прве следбенике Христа било је откриће да патња, несугласице и могућност смрти не мимоилазе ни оне који су ученици. Свети апостол Павле, чију су мисију и служење непрестано излагали одбацивању, прогону, насиљу и затворима (2Кop 1, 59; 11, 24-28; Дап 13, 50; 14, 19; 16, 19-24; 21, 30), што је коначно довело до његове смрти, ове борбе никада није оценио неуспехе, него једноставно као неизбежни аспект учеништва у Христу (Рим 8, 18-25). Затворен, Свети Павле се радује и пева хвале Богу (Дап 16, 25).

Из тог разлога, у хришћанској Цркви постоји благочастиво предање, које се с правом поштује, да се болови прихватају у знак састрадавања са Христом, и да се сматрају за учешће у његовим патњама (Фил 2, 8). ${ }^{15} \mathrm{Me-}$ ђутим, ово не сме да се узима тако да се подразумева да је бол суштински добар или пожељан. Напротив, бол остаје да представља један зли уљезни упад у људски живот којем би се требало, у нормалним околностима, одупрети. То се огледа у хришћанској дужности бриге за оне који пате. Истовремено, како је показало хришћанско сведочење кроз векове, често када смо најрањивији управо, тада сазнајемо право значење вере: њена преображајна моћ може нам давати и храбрости и снаге да охрабримо оне који пате.

3. Живот и смрт и откривена воља триједног Бога. Из хришћанске перспективе, наш живот је врховни дар јединственог триједног Бога: Оца, Сина и Светог Духа. Почетак и крај живота су у његовој власти: „Којему је је у руци душа свега живога и дух свакога тела човечијега“ (Јов 12, 10). Као што је наша Комисија раније изјавила: „Чином стварања Бог у постојање уводи људска бића са слободом да воле како Бога, тако сабратска створења. Бити човек значи познати, волети и одушевљавати се у Богу, као и учествовати у животу Бога колико је створеним бићима могућно. [...]. Кроз Пад људи бирају да живе изван богочовечанског заједничарења, доносећи у свет дисхармонију, патњу и смрт. Упркос томе, творевина наставља

15 Chryostomos, 2017; Breck, 1998, стр. 22. 
да пројављује божанску намеру, и кроз Христа Бог нуди опроштај и обновљење свеколике творевине (Рим 1, 20; 8, 18-21). Аутентични однос са Богом кроз Христа. Пун потенцијал људске личности откривен је у Христу, Духом Светим. У Христу ми смо лицем ка лицу суочени са Оцем (Jн 14, 9). У Христу ми смо такође оспособљени да суочимо сеঠе са̂ме и једни друге онаквима какви истински јесмо“. ${ }^{16}$

Стога, сваки покушај да се границе живота прецизно дефинишу, а да се посматрају само у смислу људске воље, мисли, одлуке или вештине, лишава живот сваког препознавања његове светости - светости што је дарована и остварена кроз повезаност са Богом у Христу Духом Светим. Чисто биолошка, друштвено-политичка или чак културно-научна одређења живота у потпуности су неадекватна, ако то не узму у обзир. ${ }^{17}$ Бог је створио људско биће са телом и душом који се налазе у нераскидивом јединству. ${ }^{18}$ Међутим, то јединство се раскида када смрт наступи. У смрти се тело растаче, али се душа задржава како би се поново сјединила са васкрслим телом. Заиста, у складу са васкрсењем Исуса Христа, с надом чекамо „васкрсење мртвих и живот будућег века“"

Из перспективе вере, прави значај садашњег живота треба остварити само кроз потенцијал човека за обнову и искупљење, што се постиже заједничарењем са триједним Богом. Без духовног живота, утемељеног у органском животу Цркве, нарочито у Евхаристији и другим светим тајнама, очување људског биолошког или друштвеног живота губи пуну важност. У последњој инстанци, такав живот је лишен смисла. Заиста, такав живот може само да рециклира смрт, то јест да изнова потрђује смрт. Јер, „оваплоћењем, распећем, васкрсењем и вазнесењем - и продужењем тих догађаја у светотајинском животу - читаво човечанство, заједно са свом твари, позвано је да учествује у Божијем спасоносном деловању“. ${ }^{20}$

Од тренутка биолошког зачећа, људско биће додирује искуство смрти: било кроз „природне“ процесе старења у телу, било кроз физичку или психолошку болест, било кроз доживљај емоционалне боли и стрепње. Међутим, смрт и њене последице су у потпуности превладане и трансендиране кроз Исуса Христа. Наше Цркве, англиканска и православна, слажу се да је смрт догађај који је повезан не само с крајем биолошког живота, већ и са целокупношћу људског постојања.

Пошто се из перспективе вере живот пружа даље од биолошке смрти, начин на који неко себе води у овом животу може имати далекосежне

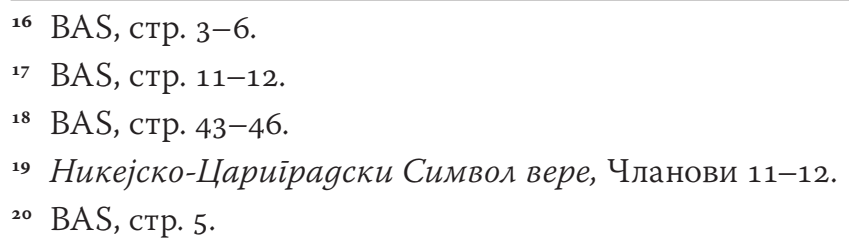


36 | Лубардић, Б., Хришћанско разумевање смрӣи и йроблем еуйаназије

последице за следећи. Према речима англиканског теолога Џеремија Тејлора: „Онај који би да умре добро, морао би се свих дана свог живота постављати као на дан смрти “21. ${ }^{22}$ Гледано из те перспективе, смрт престаје да буде појединачни догађај и постаје начин постојања, чији део чини читав земаљски живот. „Смрт“ у том схватању почиње убрзо након што смо рођени, и сходно томе, уметност доброг умирања би у идеалном случају требало да почне када смо доброг здравља, пре него што се суочимо са крајем земаљског живота.

То је у великој супротности са оним савременим секуларним погледима, који смрти приступају (нарочито у вези са потпомогнутим умирањем) као засебном људском праву, а над којом би требало да се дозволи људским бићима да врше контролу, а не као догађају који превазилази људско биће и јесте дар Створитеља, у оној мери у којој омогућава да наставимо даље, на крају до потпуне обнове у васкрслом Христу. У том смислу, из перспективе вере, то питање значајно превазилази питање људских права.

3. Умрети добро. Нису све културе, било прошле било садашње, имале исто разумевање тога шта значи имати „добру смрт“, што је дословно значење израза „еутаназија“ (eu = добро; thanatos = смрт), ${ }^{23}$ иако постоје тачке додира.

Слично томе, иако људи свих вероисповести или неверујући могу да осећају потребу да саосећајно реагују на ситуације патње и смрти, могу постојати разлике у тумачењу онога шта конституише такав одговор. Околности смрти, унутрашње настројење особе која суочава смрт, и „оквир значења" те особе, могу такође бити од велике важности у одређивању тога шта чини једну добру смрт: ту чињеницу препознају и верујући и водеће фигуре модерне секуларне палијативне неге.

Модерни постпросветитељски западни свет при вредновању живота истиче квалитете као што су аутономија и независност. У односу на такво културално залеђе, разумљиво је да страхови који се односе на смрт и умирање, најчешће изражени у таквом контексту, имају тенденцију да фокусирају немоћ, губитак достојанства, губитак способности и губитак контроле, као и страх од бола. Стога, чак и у околностима у којима се бол може контролисати, расправа о „квалитету живота“ за оне који умиру бива настављена. У том смислу, добра смрт може се проценити као она у којој је аутономија сачувана по сваку цену, а апел на појединачно људско право на самоопредељење постаје крајњи (ако не и једини) релевантан критеријум у расправи. ${ }^{24}$ Тамо где се сматра да то јесте случај, крајњи саосећајни

\footnotetext{
21 Taylor, $1651=2005$.

22 Clarke, 2017.

${ }^{23}$ Chrysostomos, 2017.

${ }^{24}$ Jones, 2017.
} 
одговор постаје онај који пре свега поштује такву аутономију. У култури која такву вредност придаје појединчевим моћима самоопредељења, терминална болест може се представити као подручје људског живота у којем имамо најмању контролу - осим у убрзавању њеног смртног исхода.

Штавише, култура која толико цени квалитете као што су снага и аутономија појединца, не може да препозна дубоке дарове који могу пратити искуство рањивости и примања „служења“ од других у стању рањивости. ${ }^{25}$ Без обзира да ли јесмо или нисмо људи од вере, ми смо створења која су предзначена да пронађу своје испуњење у односима, ${ }^{26}$ са свим изазовима и сложеностима које то укључује. Нарочито у западним културама није ретко да се чују старији или смртно болесни људи како се изјашњавају о жељи да не буду „терет“ за њихове вољене. Ако је оgнос заиста саставни део наше целовитости као људских бића, та чињеница сама по себи позива на упит-реакцију: Зашто би било проблематично прихватање животне фазе у којој наша сопствена људска рањивост захтева саосећајни и подржавајући одговор оних који нас окружују? Супротно томе, наша потреба да се научимо саосећању и стрпљењу у бризи за слабе и рањиве може у нама створити особине, можда претходно неоткривене или непрепознате, које могу продубити нашу сопствену човечност.

Иако се унутар увида секуларне палијативне неге може наћи неко заједничко тло, у свим тим областима хришћанско предање нам даје једну карактеристичну мудрост, укорењену у стварности прошлих искустава и информисану увидима вере.

4. Хришћански критеријуми за добро живљење и добро умирање. Англиканска и православна традиција сједињене су у темељном исповедању да, пошто су наши животи драгоцени дар од Бога (Пост 1, 26-27) 27, следи да је намерни прекид живота суштински погрешан. Нико нема право да нам одузме живот (Изл 20,3; Мт 5,21): нити, што би било сагласно предању хришћанства, ико има право да самом себи одузме живот (иако, као што ћемо напоменути, трагични губитак живота самоубиством природно изазива пасторални и саосећајни одговор, посебно према онима који су остали без најближих $\left.{ }^{28}\right)$.

У исто време, и англиканци и православни тврде да људски живот сам по себи није највеће добро. Дакле, иако имамо Богом-дану дужност да сачувамо живот, не мора нужно да следи да треба да тражимо начине да га продужимо по сваку цену. Штавише, обе традиције, англиканска и православна, гледају пример дат у животима светитеља (чији су животи

${ }_{25}$ Hemmings, 2017; Joyce, 2017.

${ }^{26}$ Lubardić, 2019, стр. 160.

27 BAS, стр. 3-4, 7-8.

${ }^{28}$ Hemmings, 2017. 
обликовани несебичним предавањем вољи Божијој у Исусу Христу Духом Светим) ради нашег разумевања добре и племените смрти. Заправо, унутар табора модерне Англиканске цркве, архиепсикоп Десмонд Туту (Desmond Tutu) је дао чувени исказ - тврдећи да ће се супротставити режиму апартхејда, чак ако би то резултирало његовим убиством - да смрт није најгора ствар која се може догодити хришћанину. Сведочење безбројних хришћанских мученика подржава такав став. „За мене је боље да умрем за Христа, него да царујем целим светом [...]. Тражим онога који је ради нас умро: онога хоћу који је за нас васкрсао. Ближи ми се рођење“..9 Дакле, у екстремним ситуацијама може се догодити да човек може, а понекад и треба, да положи свој живот за неко веће добро (Јн 15, 13). Занимљиво је да се у прехришћанској класичној традицији „добра смрт “ доживљавала као природна смрт која се дешава када живот дође до краја; или, као часна смрт, која је се повезивала са јуначким чином или жртвом. ${ }^{30}$

Смрт без бола увек је људски пожељна и нешто на чему треба да будемо благодарни. Стога се Православна црква моли да „Крај живота нашег буде хришћански, ठез бола, непостидан, миран", ${ }^{11}$ а у одређеним ситуацијама се моли Богу да подари мир онима који пате и чији је бол неизбежан. Међутим, у погледу вере, унутрашње настројење оболелог најважнији је чинилац у утврђивању да ли је смрт добра смрт. Из перспективе вере, смрт је „добра“ не нужно због одсуства бола. Заиста, бол је понекад неизбежан (чак и уз добробити софистицираних медицинских интервенција), и, овде корачамо по светом тлу. Јер, у таквим околностима, хришћанин се охрабрује да прихвати своју стварност са стрпљењем и надом у Бога и да страх остави по страни, сигуран у божанску љубав која надилази смрт: „У љуঠави нема страха, него савршена љубав изгони страх напоље“ (1)н 4, 18).

Слично томе, иако нас озбиљна болест може лишити многих ствари које ценимо и узимамо здраво за готово када смо здрави, из перспективе вере, она нас такође може поштедети неких искушења која нас воде у грех и одвајање од Бога и једних од других. На крају живота нема много простора за таштину, понос или самозадовољство. У том смислу, озбиљна болест је прилика за душу да се „одене за вечност “"32.33 Тамо где се бол суочава стрпљењем, чистом савешћу и вером у спасоносну руку Христа, Сина Божијег ${ }^{34}$, парадоксално, он поседује потенцијал да постане преображајан, не само за оне који пате, већ и за оне који пружају бригу, стрпљење,

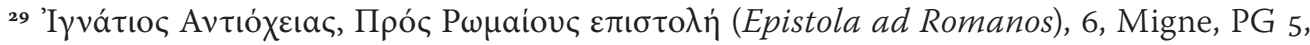
692B-C.

3o Chrysostomos, 2017.

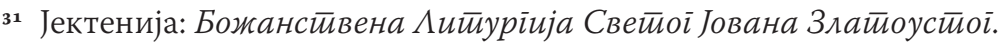

32 Taylor, 1651 = 2005; такође видети: Taylor, $1650=2005$.

33 Clarke, 2017.

${ }^{34}$ BAS, стр. 47-49.
} 
љубав и саосећање. ${ }^{35}$ Мада, то такође може много да кошта. Искуство посматрања вољене особе како пати може бити праћено агонијом (отуда потиче право значење речи саосећање: „патити-са“ [em-patheia]).

Заиста, гледано из перспективе хришћанске духовности, „добра“ смрт није увек лака ствар, нити је „лако “ умирање нужно пожељно, јер много тога зависи од контекста и унутрашњег настројења појединца (у традиционалном смислу, стање нечије душе). Свети Јован Златоусти пита: „Да ли је смрт Јована Крститеља била лоша, јер му је глава одсечена или Стефанова зато што је био каменован, или многих мученика чији се живот завршио страшном патњом? ${ }^{36^{\prime \prime} 37}$ Његов одговор је да ниједна од њих није била лоша смрт. Лоша смрт је она која се догађа у контексту непокајаног греха и недостатка мира у нечијој души. Процена древне Цркве о доброј смрти било које особе била је условљена њеним покајањем и разрешењем од греха у име Христово и према вољи небеског Оца.

5. Истински квалитет живота: живети у Христу. Кад год се расправља о потпомогнутом умирању, редовно се користе аргументи који се односе на квалитет живота. Као што је горе напоменуто, у западној култури квалитет живота се генерално оцењује материјалистичким и утилитарним критеријумима, са тенденцијом да се хедонистички тумаче и воде захтевом за избегавањем нелагоде. Највећи страхови, који су често изражени, тичу се слабљења способности и повећања рањивости, са последичном зависношћу од других.$^{38}$ Међутим, иронично је да је (мећу)зависност саставни део пуноће људског живота у љубави и заједници. У све више секуларном и атеистичком етосу данашњег западњачког начина размишљања, којем недостаје било какав шири оквир значења, смрт је дубоко проблематична: неприродан и застрашујући упад у стварност. ${ }^{39}$ Ипак, људски живот није само биолошка, него и духовна стварност, која раскринкава једнодимензионалну и кратковиду природу атеистичког приступа.

Парадоксално, из хришћанске перспективе, прихватање наше смртности може послужити да обогати, а не да умањи нашу способност за богат живот који Исус нуди. Истински квалитет живота мора се посматрати из обухватније перспективе. Та перспектива превазилази само биопсихолошке или социо-економске тачке оријентације. То је чињеница која се, понекад, препознаје у секуларном палијативном збрињавању, као и у очима вере, тако да у том погледу пружа додирну тачку. Међутим, постоје

\footnotetext{
35 Jones, 2017; Hemmings, 2017.

${ }^{36}$ Chrysostomos, 2017.

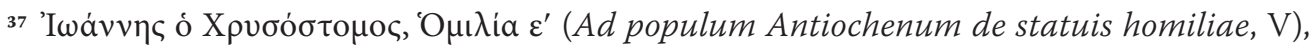
Migne, PG 49, стр. 71.

38 Jones, 2017; Joyce, 2017.

39 Clarke, 2017.
} 
40 | Лубардић, Б., Хришћанско разумевање смрйи и йроблем еуйаназије-

и неке тачке неслагања: одређења достојанствене смрти у секуларном говору могу се односити на одупирање рањивости и беспомоћности. Хришћанско одређење, међутим, потврђује оно достојанство које долази са смрћу, ако умирући Духом склапа мир са Богом у Исусу Христу, потврђујући наду у победу вечног живота.

У последњој анализи човечанство је позвано и да призна своју смртност и да се истовремено бори против ње $(1$ Kop 15,26$)$. То значи да су у нашем хришћанском искуству ношење крста и васкрсење нераздвојни: „...као они који умиру и ево смо живи“ (2Кор 6, 9). Позвани смо да се мењамо и растемо у благодати и вери, да постанемо више слични Христу. [...]. Смрт се може прихватити као средство учествовања у Христовом самоиспражњењу. Бог нам у Христу омогућава да искусимо непрестаност живота, односно сједињење с Христом, и на тај начин да преокренемо смрт самом смрћу..."4о. Као што пасхална химна Православне цркве сведочи: „Христос васкрсе из мртвих, смрћу смрт сатре, и онима у гробовима живот дарова“.

Када постоји вера у Бога и у загробни живот, где ће се Царство Божије потпуно појавити: или, много више, када се садашњи живот сматра фазом припреме за живот који ће доћи, тада патње садашњег живота никада не чине тај живот осиромашеним (што такође има последице за приступе вештачког убрзавања смрти). Ово је један од разлога из које их апостол с великом радошћу узвикује: „Радујте се свагда у Господу, и опет велим: Радујте се!" (Фил 4, 4). ${ }^{41}$

6. Допринос медицинских наука. Унутар оних култура које могу приступити њеним благодатима, еволуирајући и све софистициранији напредак медицинске науке трансформисао је бригу о патњи и умирању. Неке болести које су некада биле терминалне сада се могу спречити или излечити, а дуговечност се повећала. Неупитно је да се сматрају добродошлим и медицински напредак и интервенције које могу олакшати бол и ублажити стања која би раније скратила живот: људска вештина и домишљатост су у основи дарови које дарује Бог.

Међутим, такав напредак створио је нови спектар етичких питања и изазова који су релевантни за све, али нарочито за људе вере. На пример, у ком тренутку интервенција усмерена ка очувању људског живота постаје непримерено и вештачко продужење живота изван његовог природног завршетка, продужујући тако процес умирања? Медицински напредак непрестано мења параметре могућег. То не само да додатно усложњава процес етичког доношења одлука, већ утиче и на наше одлуке о томе

40 BAS, стр. 49.

41 Vlachos, 2016. 
како доносимо одлуке. ${ }^{42}$ Да ли је ово „средње подручје“ подручје у којем би искључиву слободу одлучивања требали да имају само - појединци?

7. Живот као божански дар: личност, заједница и одговорност. Примећено је да је идеализовани концепт аутономног појединца, конструкта касне модерне, карактерисао ставове и претпоставке савремених западних друштава. Слободни избор, самодовољност, самоодређење и економска продуктивност, посматрају се као крајња „добра“ у људском животу. ${ }^{43}$ То је заузврат имало дубок утицај на сагледавање процеса смрти и умирања. Парадоксално је да су такве претпоставке (посебно илузија да људска бића могу да имају крајњу контролу над својим судбинама), поред тога што су културолошки специфичне (и представљају тежње које су ускраћене многим људима на нашој планети), узете независно од животне стварности. Повећана секуларизација је такође допринела претпоставци да одлуке које се односе на очување или прерано окончање живота спадају искључиво у домет појединачних људских права. Као исход тога, покрет за легализацију потпомогнутог умирања добија све већи замах.

Насупрот таквом погледу на свет, Црква, Тело Христа нашег Спаситеља, распетог и васкрслог за спасење света (1Кор 2, 2; Кол 1, 18-20; Jн 6, 51), износи потпуно другачији скуп перспектива. Посебно је упутно размотрити разлоге из којих Црква, традиционално, осуђује самоубиство. Одлука појединца да одузме сопствени живот не указује само на потпуно одустајање од вере у Божији промисао, већ и на порицање да је животни дар сам по себи драгоцен и Богом-дан. То подразумева кршење шесте заповести: „Не убиј “ (Изл 20,13).

Осим тога, Црква је одувек истицала да су живот и смрт људског бића од значаја не само за тог појединца, као самосталног субјекта, већ и директно за његове или њене ближње, и, изван тога, за самог Бога. Јер, људско биће није пука индивидуа, већ личност обдарена одговорношћу44 према другима: „...створена по образу и подобију Божијем, благословена благодаћу да буде сарадник божанском у настављању рада стварања" (Пост 1, 27-28) 45 .

Иако нам је дата слобода избора живота или смрти, ми нисмо „власници“ свог живота: живот је дар од Бога: „ставио сам пред вас живот и смрт [...]; зато изабери живот да будеш жив, ти и семе твоје“ (Пнз 30, 19). Због тога су и Англиканска и Православна црква традиционално осуђивале самоубиство, понекад признајући погубну стварност психолошких чинилаца попут депресије и менталних болести. У таквим случајевима Цркве су препознале потребу да реагују саосећајно. Заправо, у Англиканској

\footnotetext{
42 Jones, 2017.

43 Jones, 2017.

${ }^{44}$ Lubardić, 2019, стр. 158, 162.

45 BAS, стр. 7.
} 
цркви, прописи који спречавају оне који су себи одузели живот да добију потпуну хришћанску погребну службу или буду сахрањени у освештаном земљишту, сада су званично укинути.

Упркос неким дубоким разликама у перспективи од оних што их поставља секуларни свет, једна ствар у којој наше Цркве, англиканска и православна, могу позитивно да допринесу расправи о потпомогнутом умирању, укорењена је у нашем исповедању да истински значај живота и смрти не треба постављати у оквир појединачних права, већ у контекст зајеgнице са Богом и нашим ближњим. ${ }^{46}$ То подразумева проширење концепта људских права, који треба да одражава и права других: посебно права наших сродника, суседа и шире заједнице за које смо подједнако одговорни и са којима градимо нераскидиву мрежу замршених односа. Превазилажењем индивидуалистичког приступа разумевању људских права могу се поштовати и права других, који желе да нам служе и да нас воле. Свети Кипријан Картагински рекао је: „Сви падају сами, али ми се спасавамо у заједници“. ${ }^{77}$ Међутим, постојање таквих мрежа одговорности (Јн 5, 7-8), како хришћанских тако и нехришћанских, пружа заједничку основу за дискусију.

У којој мери Црква може смислено и на одговарајући начин одговорити на дискурсе модерних секуларних наука и друштвених култура? Питање вокабулара овде може бити од критичне важности као руководно правило: конкретно, могу ли хришћани реконтекстуализовати и реинтерпретирати хришћански речник тако да буде разумљив секуларној култури, на начин који омогућава Цркви да остане присутна и релевантна за савремени свет?48 Такав приступ би омогућио хришћанима да изграде критичка становишта у вези са политичким и етичким ефектима развоја, као што је расправа о потпомогнутом умирању. Међутим, такође би се захтевало да теологија буде способна да се укључи у дискурс модерне науке, етике и политике на компетентан начин: чувајући сложеност и осетљивост различитих друштвено-политичких и културних контекста. Хришћани треба да рукују савременим културалним речником, али, и да га истовремено критикују како би одбацили некорисне претпоставке и избегли такве замке које, на пример, имплицитно подразумевају претварање особа с инвалидитетом у некакву под-људску врсту. То подстиче Цркву да ствара одговоре способне да се ухвате у коштац са разним јавним проблемима, у специфичним ситуацијама.

Уједно, треба признати да секуларни свет има свој „дневни ред“, који је понекад у великој супротности са циљевима Цркве, којој је суђено да сведочи вољу Божију. Црква је Еклисија - сабрање оних који су „позвани“

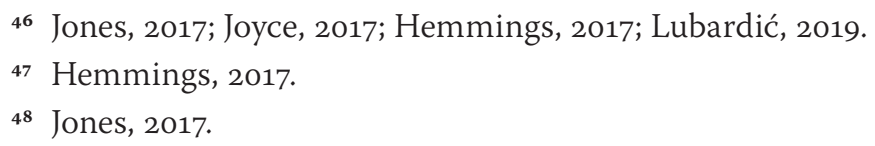


из света: „...нисте од света него вас ја изабрах од света“ (Јн 15, 19). Притом, то је мултиконтекстуални свет који се брзо мења. Речима англиканског романописца и теолога Клајва С. Луиса: „Ако прочитате историју, установићете да су хришћани који су учинили највише за садашњи свет управо они који су мислили највише на будући век"49.50 У Цркви, наше традиционално теоцентрично и христоцентрично настројење значи да ми учимо свет небеском језику жртве и жртвене љубави, а избегавамо да опонашамо или подржавамо помодни световни новоговор.

\section{8. Теолошко размишљање о животу и смрти: контекстуални при-} ступи кључним питањима. Да се вратимо на полазиште, ниједна расправа о смрти и умирању не може да не укључи тешке случајеве трајне патње, било да су везане за терминалне или хроничне болести, инвалидност и неизлечиви бол. У таквим околностима неопходно је опипљиво саосећање. Притом, мора се признати и то да се на основу тешких случајева, ако постану искључиво а универзализовано мерило, изводе лоше законске одредбе. Једнако је важно да, као англиканци и православни, проналазимо начине да заједно разговарамо о питањима духовног и моралног расуђивања везаног за крај живота. ${ }^{11}$

Наше Цркве су директно укључене у пастирско збрињавање, имају велико искуство у „питањима живота и смрти“ и поучавају преко наших локалних парохија, респективно. Стога смо изванредно добро позиционирани да доприносимо широј јавној расправи на свим нивоима на начин који је мудар, саосећајан, добро обавештен и који се не боји да говори о стварности смрти и умирања. Друштву је потребна широка и уравнотежена расправа која се протеже што је могуће шире око питања смртности, у којој је потпомогнуто умирање само један мали део.

Кључна питања која наше Цркве могу да поставе како би утврдиле потпуну истину сваке такве изазовне ситуације, укључују следећа: Ко има моћ? Чији гласови добијају највећу тежину? Чији су гласови искључени? У чијим рукама леже одлуке? Ко је обогаћен или осиромашен било којим начином деловања - не само финансијски, већ и емоционално, духовно и друштвено? Како се бавимо питањем људских права и како изгледа правда из свих ових перспектива?52

Поред тога, какве су импликације за адекватно финансирање палијативног збрињавања и за старање за оне које друштво мање вреднује: слабе, старије, оне који пате од менталне болести или деменције - за оне који нису нужно смртно болесни, али који можда нису у стању да економски

\footnotetext{
49 Lewis, 2001, стр. 134.

50 Hemmings, 2017.

${ }^{51}$ BAS, Preface, ix.

52 Jones, 2017.
} 
допринесу друштву (што их може у политичком и економском смислу учинити суштински „проблематичним“)? Које силе су на снази и покрећу расправу према непримереним аргументима заснованим на финансијским, техничким, бирократским и законодавним сврсисходностима?53 Како се англиканци и православни и њихове Цркве труде да дају глас обесправљенима, заштите рањиве и осигурају да се онима који их највише требају, посебно онима који су суочени са терминалном болешћу, пруже потпуна правда, свеобухватно разумевање и одговарајућа брига? Ово су посебно изазовна питања, с обзиром на то да су контексти којима се бавимо, и то у глобалном захвату, неизбежно вишеслојни и укључују правне и културне референтне оквире.

\section{9. Црква у контексту: смртност и расправа о потпомогнутом уми-} рању. У вези с овом дискусијом мора се признати да и Црква има свој контекст, као и своје унутрашње поделе и различите перспективе. Постоји шири хришћански консензус о грешности убиства (иако питање „праведног рата“ за неке омогућује изузетке), а такође, историјски, у вези са самоубиством (мада, као што је горе наведено, трагедија самоубиства увек изазива осетљив пастирски одговор: и перспективе и праксе, посебно у оквиру англиканства, донекле су се измениле у последњим деценијама). Али, шта је са одговорима наших Цркава на горуће питање потпомогнутог умирања?

Постоје различити облици које потпомогнуто умирање (assited dying) може да има. То, надаље, покреће различите облике моралних питања (не само да ли тај процес има активни пристанак укључене особе или не, и за кога се процењује да може дати такав пристанак). Екстремнији облици невољне и принудне еутаназије ${ }^{54}$ одвратни су и неприхватљиви како Црквама, тако и цивилном друштву уопште тако да они овде могу заузети заједничку позицију. Али, које сложеније и нијансираније облике потпомогнуто умирање може да добије?

А. Прво, ту је намерна и активна људска интервенција која има за циљ да убрза смрт, а која има за циљ да ослободи особу од последица неизлечиве болести или неиздрживог телесног или психичког бола. У априлу 2001. године, у оквиру Европске уније, Холандија је легализовала консензуалну помоћ лекара при умирању из разлога људског саосећања. Пример Холандије следила је Белгија отприлике годину дана касније са мање строгим условима, а остале земље су потом то следиле. У већини земаља ово је и

53 Jones, 2017; Joyce, 2017.

54 Спецификујмо: Када је сагласност пацијента присутна, имамо случај (1) добровољне еутаназије. Еутаназија је (2) невољна кад пацијентова воља на било који одређени начин не постоји. Тамо где се еутаназија врши против пацијентове воље, имамо (3) принудну еутаназију. 
даље незаконито, мада постепено померање друштвених ставова указује на слабљење отпора. Цркве су највећим делом уједињене у свом противљењу овом облику потпомогнутог („еутаназијског“) умирања.

Б. Друго, имамо случај у коме се смрт убрзава као резултат смањивања или ускраћивања лекова, храњења или хидратације који одржавају живот. Типичан пример је случај када се сматра да је појединац у сталном вегетативном стању (PVS) или минимално свесном стању (MCS). 55 У Великој Британији постоје правни процеси који могу дозволити ускраћивање вештачке исхране и хидратацију у таквим околностима.

B. Треће, до недавно дискусија се односила на такозвани „принцип двоструког ефекта“" (аргумент да употреба опиоида од стране медицинске струке, када се примењује са примарним циљем контроле симптома, може легитимно резултирати скраћивањем живота као секундарне последице те интервенције). Истраживања су од тада показала да се ради о заблуди. Супротно ранијим претпоставкама, они који примају повећане дозе опиоида за контролу бола на крају живота не показују краћа времена преживљавања од оних који их не примају у повећаним дозама. Заиста, парадоксално, контрола бола (која смањује ниво патње пацијента) може имати ефекат продужења животног века. ${ }^{56}$

Православна црква је јасна у супротстављању потпомогнутом умирању и било којој другој врсти интервенције која убрзава процес умирања и на тај начин спречава вољу Божију. 57 У ствари, и англиканци и православни су умногоме сложни у својој темељној супростављености потпомогнутом умирању. Англиканска црква, често делујући са екуменским или другим верским партнерима, у великој се мери противи легализацији потпомогнутог самоубиства (у смислу „еутаназирања“ болујућег). ${ }^{8}$ У Англиканском кругу несумњиво постоје и дисонантни гласови, они који се томе не противе (у „одређеним“ случајевима), али, они су у овом тренутку мањина.

Истовремено, у Англиканству постоји значајан консензус око слободе појединца да одбије лекове или реанимацију и да одбије лечење за које пацијент сматра да је постало узалудно или оптерећујуће. У одрећеним пажљиво оцењеним случајевима, повлачење или одустајање од лечења може се сматрати прихватљивим из разлога саосећања.

10. Биоетичка рефлексија о еутаназији: медицински, научни и идеолошки аспекти. Онима који могу да јој приступе, савремена медицина

55 Медицинска струка прави разлику између таквих стања и стања праве коме: стања које ретко траје дуго ठез инвазивне медицинске подршке, јер пацијент или умире или поново добија свест. Видети: Turner-Stokes, 2016.

${ }^{56}$ Fohr, 1998.

57 Chrysostom, 2017; Dragas, 2017; Hemmings, 2017.

${ }^{58}$ Jones, 2017; Joyce, 2017; Clarke, 2017. 


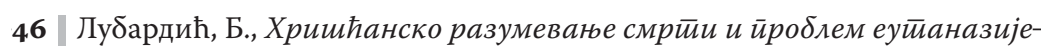

омогућава очување живота вештачким путем, чак и у ситуацијама када нема наде за позитиван исход за пацијента. У коначној анализи, како се слажу чланови Комисије, потоње може представљати продужење процеса

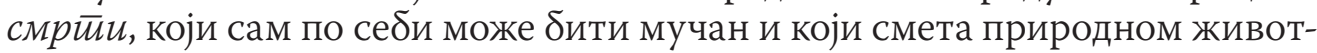
ном циклусу на начин који може бити од незнатне користи за пацијента. Могло би се тврдити да би омогућавање појединцу да се суочи са стварношћу смрти без прибегавања оваквој интервенцији него уз поверавање себе вољи Божијој представљало природан приступ смрти.

То је био приступ који се традиционално следио у прошлости, а могао би се следити и у садашњости (уз признање да демаркациона линија између продужавања живота и продужавања умирања можда није увек очигледна, као и да је сложено покушати разлучити шта јесте, а шта није „природно“). Ако се људска смрт збива по Божијем промислу и допуштењу, ми смо онда „под старатељством нужности“59. Према пророку Давиду, „у књизи је твојој све то записано, и дани забележени“ (Пс 139, 14-17).

Употреба биотехничких средстава у савременој науци и медицини несумњиво може компликовати расправе око питања краја живота. Одлуке о очувању живота могу укључивати трансплантацију органа (људског или потенцијално нељудског порекла): а то је тема о којој Цркве могу имати различита становишта. Ово такође подразумева вештачко одржавање даваочевог тела. Тамо где су ресурси ограничени или натегнути, медицинске одлуке о прекиду лечења за једног пацијента у циљу спасавања другог такође могу бити сложене и нејасне.

Софистицирано пренатално тестирање може открити све шири спектар абнормалности и недостатака током развоја ембриона, а терапијски побачај таквих ембриона рутински се нуди у многим западним клиникама. Ово позива на тражење одговора на питање чијим се интересима служи када се таква одлука донесе; као и какве би последице то могло да има на друга средства регулисања друштвеног тела. Који су критеријуми који треба да се користе и на који се начин разликују од некадашњих покушаја регулисања друштвеног тела еугеником (где су, на пример, питања расе, пола, старости или економске класе итд. могла да буду узета у разматрање)?

11. Економски, правни и социјални аспекти. Економски фактори могу снажно утицати на приступ друштва смрти, палијативном збрињавању и потпомогнутом умирању, посебно тамо где се морају доносити одлуке које се односе на расподелу ограничених ресурса: на пример, треба ли старим, инвалидним, ментално болесним и другим угроженим особама пружити сва потребна медицинска средства и уобичајену болничку негу, ако се то сматра економски неодрживим или финансијски неизводљивим? Етичке и социјалне последице таквог склопа економског и правног размишљања,

59 Taylor, 1651 = 2005; Clarke, 2017. 
посебно када се оцењује суштинска „вредност“ људског живота, изузетно су опасне, водећи ка пукој економској процени људског живота. ${ }^{6}$

\section{2. Легализација потпомогнутог умирања: проблеми и после-} дице. Као што је раније напоменуто, заговорници умирања уз помоћ лекара често као главни аргумент у своју корист износе неповредивост људског права на самоопредељење. Такав приступ може да превиди да се друга кључна људска права могу кршити као последица управо те акције: такво разматрање указује на шири појам „јаства“ и последично на шире разумевање „самоопредељења“. Он нужно укључује право на самосаосећање (самосамилост) и саосећање (самилост) од других: наиме, (1) право избора на чување сопствене личности (посебно у случајевима када је невољна и недобровољна еутаназија могућа, или је то случај); (2) право на лечење одговарајућом и најефикаснијом медицинском негом (заједно са правим очекиваним трајањем палијативног лечења); (3) право на самобригу и, чак, право на заштиту од самозлостављања (посебно када је особа склона да себе повреди због менталне болести или поремећаја психолошке природе); и (4) право да се не доживи ниједан облик нечовечног малтретирања.

С обзиром на ова наведена права, могло би се тврдити да „уклањање законских казни за намерно убијање њихових пацијената од стране лекара само по себи представља озбиљну повреду одговорности владе да заштити животе својих невиних грађана, без изузетка. У Универзалној декларацији о људским правима Уједињених нација, најосновнијим људским правом проглашено је право сваке невине особе на интегритет свог живота, право које треба заштитити законом“б1 (уп. Изл 20, 3; Мт 16, 26).

Растуће озакоњивање потпомогнутог умирања и спецификовање услова у којима се његова реализација сматра дозвољеном, служе промоцији не само његове друштвене прихватљивости, већ и прећутне институционализације у оквиру прописаних законских услова. Спецификација услова под којима је потпомогнуто умирање легално и легитимно идентификује предуслове који би оправдавали некога ко ради на или сарађује у његовом остваривању. То доприноси развоју позитивне климе, у којој је потпомогнуто умирање све мање контраверзно. Неки се боје да би овај помак у параметрима оног што је прихватљиво могао, узвратно, да припреми пут за његову ширу примену, а да сагласност појединца није добијена.

Истовремено, показује се и да легитимизација потпомогнутог умирања у основи мења психолошку и моралну сврху медицинске праксе и однос лекара и пацијента: умешаност практичара у интервенције којима

\footnotetext{
6о BAS, стр. 69.

61 Pollard, 2003
} 
се убрзава смрт, уништава само ткиво традиционалног разумевања медицинске неге, које је и даље у складу са главним духовним и етичким прописима Цркве.

Претходне анализе илуструју раширеност структуралног греха, ${ }^{62}$ као и опасности својствене спуштању прага социјалне толеранције према потпомогнутом умирању. Класична тријада искушења: новац (финансијски интерес), моћ (бирократска сврсисходност) и статус (професионализација питања живота и смрти, уз истовремено укидање човечности у корист комодификације) присутна је увек и свуда. ${ }^{63}$ Хришћани имају обавезу да истражују, разоткривају и решавају такве проблеме, посебно у контексту изазова „еутаназије“.

13. Црква и пастирска брига: свеобухватан приступ. Црква је позвана да се дубоко и саосећајно суочи са тешком стварношћу људске патње, посебно са неподношљивим болом који може да карактерише крај живота човека. У пруженој подршци, у молитви и светим тајнама (посебно у исповести, светом јелеосвећењу и Евхаристији), цела Црква стоји поред онога који пати и залаже се пред Богом да умирућег ослободи неподношљивог бола, и моли се за његов или њен вечни починак у Господу, који треба да буде „све у свему“ (1Кор 15, 28). Деловање Цркве у заједничкој молитви уверава нас да Бог прожима бол својим присуством, ${ }^{64}$ проширеним и кроз бригу наших ближњих. Бог не пати „уместо“ нас, него са нама.

Пастирско пружање помоћи Цркве није ограничено само на физичку смрт, нити на земаљску страну обреда сахране. И Англиканска и Православна црква проширују своје пастирско служење, литургијски, на живот изван, у ишчекивању васкрслог Христа, који ће нам се заувек придружити у надолазећој слави Небеског Царства свога Оца (Јн 1, 5; Откр 1, 8; 4, 8). То се посебно очитује у молитвама верника пре посвећења светих дарова у Евхаристији. Литургијски календари наших Цркава такође пружају случајеве када се од нас тражи да се бавимо стварношћу смрти. Заупокојене молитве потврђују стварност физичке смрти и истину васкрсења у вечни живот ${ }^{65}$ (многе Англиканске цркве одржавају службу Свих Душа у којима се помињу мртви).

Овакве литургијске прилике могу да играју виталну улогу у помагању исцељења искуства дубоке туге ожалошћених. Стога се веома бринемо да поштујемо и сећамо се и тела ради „вечног сећања “ у Христу. Јер, Црква има ауторитет и средства благодати да опрости и препоручи покојника Господу: „Јер вам кажем заиста: штогод свежете на земљи

\footnotetext{
${ }_{62}$ Jones, 2017; Hemmings, 2017.

63 Jones, 2017.

${ }^{64}$ Clarke, 2017.

65 Hemmings, 2017.
} 
ठиће свезано на небу, и штогод разрешите на земљи биће раздрешено на небу" (Мт 18, 18).

У сведочењу о откривеној истини о Богу, свету, човечанству и спасењу, Црква може водити људе у правцу тога да стекну духовна и христоцентрична искуства која нас утемељују у Богу кроз веру, и изговарати Божији опроштај и молити се за исцељење силом Христовом (1Кор 1, 24). ${ }^{66}$ Такође, пастирска брига Цркве обухвата најдубље и најшире људске бриге. Оне се крећу од егзистенцијалних питања о смислу живота и смрти, зла, бола или патње, до конкретнијих проблема као што су брига о болеснима, њиховој родбини, медицинским биоетичарима, лекарима и медицинским сестрама, и управитељима погреба. Наравно, потребна је специфичнија пастирска нега како би се решио низ горућих питања која произилазе из биомедицинских и биотехничких настојања карактеристичних за савремено доба.

14. Духовно, болничко и палијативно служење: екуменска перспектива. Једна област у којој наше Цркве могу радити заједно, и где наше разлике могу бити минималне, односи се на оне пастирске, клиничке и духовне ситуације у којима је потребна палијативна нега. Цркве би могле поново да поведу према холистичком приступу окончању животне неге. На пример, на Западу је учињено много са модерним покретом за хоспицију (који је од свог настанка препознао вредност таквих холистичких приступа) и Исток треба да учи од њега, јер је покрет за хоспицију још у повоју у источним земљама. Истовремено, Запад би могао много научити од Истока о бризи у породици за старије родитеље и родбину. ${ }^{67}$

Пастирска брига Цркве је свеобухватна јер се ठави и небеским и земаљским проблемима. Наше Цркве, верне распетом и васкрслом Спаситељу, који је победио смрт и отворио капије вечног живота, уједињене су у спремности да помогну људима, укључујући хришћане, да се поштено и ठез страха суоче са истином наше смртности и физичке рањивости.

15. Потпомогнуто умирање: начела за теолошку оријентацију. Упутно је увести скуп општих начела ${ }^{68}$ која се, у смислу критеријума, могу применити на питање потпомогнутог умирања, пре свега, али и на тематику ठиоетике уопште. ${ }^{69}$

А. Прво начело представља поштовање времена. Не би требало журно приступити биомедицинским апликацијама, а да нисмо претходно стекли потребна знања.

\footnotetext{
66 Vlachos, 2016; Dragas, 2017.

${ }^{67}$ Hemmings, 2017.

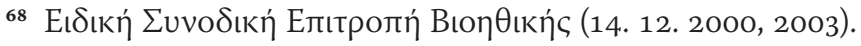

69 Vlachos, 2016; Dragas, 2017.
} 


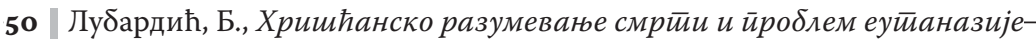

Б. Друго начело представља йошйовање према Божијој творевини. У складу са тим, научници би требало да користе своје знање са дискрецијом и опрезношћу, имајући у виду дугорочне последице њиховог рада. (Отуда, на пример, одговарајући опрез у вези са генском терапијом која, тврди се, може да уведе неповратне промене у људском друштвеном понашању. Из тог разлога је потребна посебна пажња у погледу одобравања метода генетске терапије која ће свој ефекат преносити на потомке особа које су подвргнуте терапији). Заједно с тим, људска бића имају одговорност према будућим генерацијама, али и према околини.

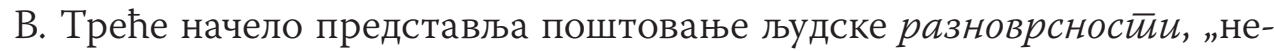
савршености" и инвалидитета. Биомедицинска знања могу се користити из других разлога, осим дијагностичких, превентивних и терапијских сврха, који могу имати опасне и непожељне последице: за отварање пута друштву које карактеришу генетска дискриминација, расизам, поступци за убрзање смрти и еугеника; такође, поседовање здравља може све више бити последица поседовања богатства.

Г. Четврто начело представља поштовање светиње људског живойа. Свако политичко или законодавно прилагођавање у вези с тим питањима треба нужно да поштује чињеницу да свако људско биће од свог зачећа до последњег даха представља јединствено незаменљиво и непоновљиво биће, ${ }^{70}$ које по природи има слободну вољу, свето је и тако од трансцендентне вредности, а оно формира један друштвени ентитет са својим правима и обавезама.

Д. Пето начело поставља да се људски живот не може свести на огољено постојање појединца, већ је у основи зајеgничан: повезан са другим људским ठићима и датом околином. Узета као божанско „допуштење“, смрт се може сматрати посебном врстом „дара“. То значи да наилазећа смрт позива појединца да се на духован начин суочи са коначношћу овоземаљског живота, сагледајући перспективу за живот изван смрти. Истовремено, како је раније речено, то збивање доприноси изградњи заједнице мобилизујући солидарност оних који се окупљају да подрже и утеше особу чији је живот на свом природном крају.

16. Закључак: надом испуњена вера - од смрти до вечног живота. Вера у Божији промисао позива хришћанина да позитивно одговори не само на здравље или срећу, већ и на болест, бол или катастрофу. Рекосмо, људско биће је створено по образу Божијем (eikon) и позвано је да стекне подобије (homoiosis) Богу духовном обновом (theōsis), што је наш крајњи циљ. ${ }^{71}$ То подразумева прихватање Божијег исцељења и праштања, уједно и ношење свог крста у борби против греха (Мт 16, 24-26). Из тога следи

7 BAS, стр. 12.

${ }^{71}$ BAS, стр. 19-21. 
да људска бића не могу правилно процењивати живот једино према мери задовољства и физичког здравља, већ морају узети у обзир и духовну димензију, радећи у сарадњи (synergeia) са Божијим Духом, подвижно и литургијски, држећи се и речи и дела Божијих у Христу르. Један од великих парадокса живота вере јесте тај да се, према Божијем промислу, далеко од повреде или слабљења људске личности, наша рањивост на крају може претворити у извор добробити и снаге.

Следећи апостола Павла можемо се сложити да наизгледна немоћ чак и трајна инвалидност или терминална болест - може садржавати снагу највишег реда, где је „моћ усавршена у слабости“ (2Кор 12, 9). Заиста је „у наизгледној крхкости јединственост људске личности може просијати најизразитије, потврђујући се и код оних који дају и код оних који добијају бригу с љубављу“.73 Ово уверење је део посвећеног хришћанског духовног живота.

У модерним временима се сматра да је добра смрт крај који је „лак“ или „угодан“. Када је то случај, занемарују се изгледи за људски живот после смрти и његов вечни интерес. Поверење и поуздање у Божију промисао бивају ослабљени. Сходно томе, све има тенденцију да се разматра у антропоцентричном смислу, индивидуалистички и несаборно. Нарочито намерни прекид нечијег живота доводи у питање перспективу и снагу вечног живљења. Стога је самопоуздано људско биће у опасности да буде лишено духовне обнове и довршетка благодаћу Божијом у Христу. Међутим, чак и у таквим случајевима Црква препоручује такву особу безграничним милосрђима Господњим: „А када се јави доброта и човекољубље Бога, Спаситеља нашега, не за дела праведна која ми учинисмо, него по својој милости спасе нас..." (Тит 3, 4-5; Јев 4, 16; уп. Пс 86, 5; 145, 9).

Непрестано се треба подсећати да је Христос Син Божији преузео тело које је било подложно патњи и смрти, али било је потпуно чисто и безгрешно, да би победио смрт која прожима природу палог човека. Сами Бог је у Исусу Христу прихватио нашу смртност и постао „послушан чак и до смрти на крсту“ (Фил 2,8$),{ }^{74}$ тако да се сви који су сједињени с њим ослободе страха од смрти и њених разарајућих учинака. Речи апостола Павла треба озбиљно схватити: „И Он узе најприснијег удела у томе, да смрћу сатре онога који има моћ смрти, то јест ђавола, и да избави оне који из страха од смрти целога живота беаху кривци за своје робовање" (Јев 2, 14-15; Рим 8, 18-21). У супротном, остајемо робови страсти, неслободе и смртности. ${ }^{75}$

72 BAS, стр. 14-15.

73 BAS, стр. 12.

${ }^{74}$ BAS, стр. 13.

75 Vlachos, 2016. 
52 Лубардић, Б., Хришћанско разумевање смрӣи и ӣроблем еуйаназије-

Ми носимо смрт у себи од зачећа, заједно са генима старења, и то нас чини склонима да гајимо егоистичне страсти, нарочито самоугађање, љубав према похвали и посесивност. ${ }^{76}$ Међутим, непрекидним покајањем (metanoia) изнова потврђујемо благодат која нам је дата првобитним облачењем у Христа, крштењем (Гал 3, 27). Оци Цркве сузе покајања називају водама „другог крштења".77 Кроз ту свету тајну умиремо и уздижемо се са Господом и непрестано се „одевамо за Небо“.78 „А кад се ово распадљиво обуче у нераспадљивост, и ово се смртно обуче у бесмртност“, објашњава апостол Павле, „онда ће се збити она реч што је написана: Победа прождре смрт" (1Кор 15, 54-55; уп. Јев 12, 24).

Живећи у Телу Христовом, Цркви, постајемо мртви за грех, црпећи моћи Христовог крста и васкрсења, духовне обнове, љубави, послушности и самоодрицања, свакодневно носећи свој крст (Лк 9,2 3). На тај начин одбацујемо страх од смрти и жањемо прве плодове истинске слободе. Заправо, само „ако вас Син избави, заиста ћете бити избављени“ (Јн 8, 36). Тако се ослобађамо у великој нади да ћемо стићи до начина живота који није ограничен грехом, смрћу и пропадљивошћу. Апостол Павле свима даје чудесно уверење:

„Ако ли живи у вама Дух онога који је васкрсао Исуса из мртвих, онај који је подигао Христа из мртвих оживеће и ваша смртна телеса Духом својим који живи у вама“" (Рим 8,11 ; Изл $37,1-7) .{ }^{79}$

Према томе, можемо рећи да је у хришћанском смислу перспектива доброг умирања она која се може схватити само у контексту доброг живљења и брижљивости, уз увек присутну свест о пролазној природи овог живота, али уз истовремено одбијање малодушности. Живот је драгоцени дар од Бога, за који благодаримо, и који примамо, пуни наде. Закључак Џеремија Тејлора у Свейом Умирању лепо сажима целу ствар:

„Остаје да ми који смо живи треба да живимо тако да кроз дела вере присуствујемо Дану Господњем: да се не изненадимо нити да напустимо своје дужности несавршени, да наше грехе не оставимо непокајаним, да наше размирице са другима не оставимо неразрешеним, да Бога не оставимо незадовољним; него кад се спустимо у наше гробове, да можемо да почивамо у наручју Господњем, све док се не припреме дворови где ћемо вечно певати и славити. Амин“"

\footnotetext{
${ }^{76}$ Vlachos, 2016.

77 Clementis Alexandrini, Quis Dives Salvetur, Migne, PG 9, 603A-652C: 649CD; Ephraem

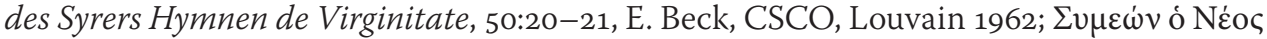

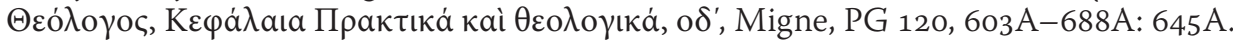

${ }^{88}$ Clarke, 2017; Hemmings, 2017.

79 Vlachos, 2016.

8o Taylor, 1651 = 2005; Clarke, 2017.
} 


\section{Прилог}

\section{Међународна комисија за англиканско-православни теолошки дијалог: списак редовних чланова из 2018. године}

Сапредседавајући са англиканске стране: Архиепископ армашки др Ричард Кларк (Црква Ирске)

Сапредседавајући с православне стране: Митрополит белгијски, Атинагора (Цариградска Патријаршија)

Представници Православне Цркве: Митрополит Зимбабвеа Серафим (Александријска Патријаршија), Протојереј Џонатан Хемингс (Антиохијска Патријаршија), Протојереј професор др Георгије Д. Драгаш (Јерусалимска Патријаршија), Професор др Богдан Лубардић (Српска Патријаршија), Митрополит трговиштански Нифон (Румунска Патријаршија), Протојереј професор др Георгије Звиададзе (Грузијска Патријаршија), Професор Натан Хоуп (Албанска Црква), Митрополит китионски Хризостом (Кипарска Црква), Професор др Милтијадис Константину (Грчка Црква) и Протојереј др Христос Христакис (сасекретар) Чланови Комисије који нису присуствовали скупу: Протојереј професор др Валентин Васечко (Московска Патријаршија) и Епископ филомелионски Илија (Албанска Црква) ${ }^{81}$.

Представници Англиканске Цркве: др Филип Аспинал (Англиканска Црква Аустралије), Умберто Маиздегу Гонклавес (Епископална Англиканска Црква Бразила), Грејем Ашер (Црква Енглеске), Каноник Алисон Џојс (Црква Енглеске), Каноник др Сара Роуланд Џонс (Црква у Велсу), Каноник Филип Хобсон OGS (Англиканска Црква Канаде), Мајкл Луис (Епископална Црква у Јерусалиму и Средњем истоку), Каноник Хосам Наум (Епископална Црква у Јерусалиму и Средњем истоку), Каноник др Џон Жибо (сасекретар) и Нил Вајгерс (Канцеларија Англиканске заједнице [ACО]). Чланови Комисије који нису присуствовали скупу: Преузишени др Роуен Вилијамс (Црква Енглеске), Пречасни отац Марк Билимориа (Црква Цејлона) и Пречасна Гчебиле Фумзиле Џина (Англиканска Црква Јужне Африке).

81 Услед проблема у вези са јурисдикцијским статусом такозване Православне Цркве Украјине (при Цариградској Патријаршији), коју Московска патријаршија не признаје, и услед спора Москве и Цариграда поводом тог питања, Московска патријаршија на скуп на Кипру (Ларнака 2018) није одаслала свог представника. Представници Московске патријаршије током четврте фазе рада Комисије били су редом: високопреподобни отац др Кирил Ховорун 2009-2011; преосвећени епископ Сурошки Јелисеј 2012, и високочасни протојереј професор др Валентин Васечко 2013-2017. 
54 | Лубардић, Б., Хришћанско разумевање смрӣи и ироблем еуйаназије-

\section{Скраћенице}

BAS $=$ The Buffalo Agreed Statement

ICAOTD = International Commission for Anglican-Orthodox Theological Dialogue

Migne PG = Jacques Paul Migne, Patrologiae Cursus Completus: Series Graeca Migne PL = Jacques Paul Migne, Patrologiae Cursus Completus: Series Latina 


\section{Литература}

Breck, J. (1998). The Sacred Gift of Life: Orthodox Christianity and Bioethics. Crestwood, New York: St. Vladimir's Seminary Press.

Clarke, R. (2017). Dressing for Heaven: Jeremy Taylor and Holy Dying (caonштење дато на пленарном скупу ICAOTD у Слиеми, Малта 14-21. октобар 2017).

Chrysostomos (2017). Response of Metropolitan Chrysostomos of Kition to the Paper of Fr George Dion Dragas on Euthanasia (саопштење дато на пленарном скупу ICAOTD у Слиеми, Малта 14-21. октобар 2017).

Dragas, G. D. (2017). On Euthanasia and the Orthodox Approach (саопштење дато на пленарном скупу ICAOTD у Слиеми, Малта 14-21. октоठар 2017).

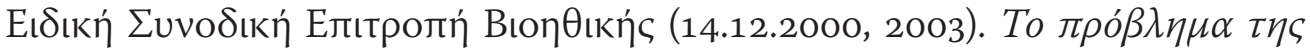

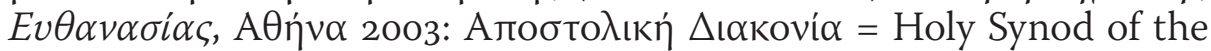
Church of Greece Special Committee for Bioethics: Basic Standpoints on the Problem of Euthanasia. Y The Problem of Euthanasia, Athens 2003: Apostolic Service.

Fohr, S. A. (1998). The Double Effect of Pain Medication: Separating Myth from Reality. Journal of Palliative Medicine, 1, 315-328.

Harakas, S. S. (2015). Contemporary Moral Issues Facing the Orthodox Christian, Minneapolis. Minnesota: Light and Life Publishing Company.

Hemmings, J. A. (2017). An Orthodox response to Death and Dying: Addressing Heaven (саопштење дато на пленарном скупу ICAOTD у Слиеми, Малта 14-21. октобар 2017).

IAHPC (2018). Global Consensus based palliative care definition. Houston, TX: The International Association for Hospice and Palliative Care.

ICAOTD. (1985). Hill H., Methodios of Thyateira (yp.), Anglican-Orthodox Dialogue: The Dublin Agreed Statement, Crestwood, NY: SVSP.

ICAOTD. (1977). Ware K., Davey, C. (yp.), Anglican Orthodox Dialogue: The Moscow Agreed Statement, London: SPCK = The Moscow Agreed Statement 1976 (y: ICAOTD 1985, стр. 50-57).

ICAOTD. (2006). Dyer M., John of Pergamon (уред.), The Cyprus Agreed Statement, London: The Anglican Communion Office.

ICAOTD (2015). Herft, R., Ware K. (yp.), In the Image and Likeness of God: A Hope-Filled Anthropology, The Buffalo Statement Agreed by the International Commission for Anglican-Orthodox Theological Dialogue (ICAOTD), London: Anglican Consultative Council. 
56 | Лубардић, Б., Хришћанско разумеване смрйи и йроблем еуйаназије-

Jones, S. R. (2017). Contemporary Anglican Approaches to Thinking and Acting Well on Death and Dying (саопштење дато на пленарном скупу ICAOTD у Слиеми, Малта 14-21. октобар 2017).

Joyce, A. (2017). Anglican Approaches to Death and Dying: An Anglican Response to the Papers by Richard Clarke, Archbishop of Armagh, and The Revd Canon Dr Sarah Rowland Jones (саопштење дато на пленарном скупу ICAOTD у Слиеми, Малта 14-21. октобар 2017).

Lubardić, B. (2014). Orthodox Dialogue with the Anglican Church: ICAOTD. Y P. Kalaitzidis, Th. Fitzgerald, C. Hovorun, A. Pekridou, N. Asproulis, D. Werner and G. Liagre (yp.), Orthodox Handbook for Teaching Ecumenism (An ETE/WCC, CiD/CEC and Volos Academy Project), Oxford: WCC Publications, Geneva - Regnum Books International, 490-496. = Lubardić, B. (2013). La Commission internationale pour le dialogue entre anglicans et orthodoxes: travaux réalisés et perspectives d' avenir. Irénikon: Revue des Moines de Chevetogne, 1-2, 60-76.

Лубардић, Б. (2018). Међународна Комисија за англиканско-православни теолошки дијалог (ICAOTD 1973-2018): историја, структура, циље-

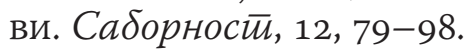

Lubardić, B. (2019). Orthodox Theology of Personhood: A Critical Overview (expanded and updated Expository Times 122:11, 122:12, 2011 version). Y Bogoljub Šijaković (yp.), Ad Orientem: Essays from Serbian Theology Today (стр. 144-188). Belgrade: Faculty of Orthodox Theology.

Lewis C. S. (2001). Mere Christianity, London - New York: Harper Collins (London: Geoffrey Bles, ${ }^{1} 1952$ ).

Mannix, K. (2017). With the End in Mind: Death, Dying and Wisdom in an Age of Denial. London: William Collins.

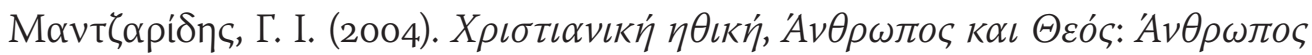

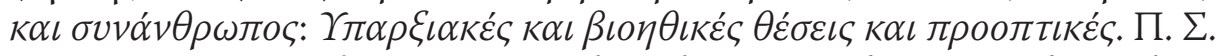

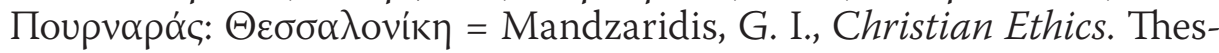
salonica: Ed. Pournaras.

McCarthy, B. (2015). Why the Church of England Supports the Current Law on Assisted Suicide. London: Archbishops' Council Church House.

MK (2018). Међународна комисија за англиканско-православни богословски дијалог. Саопштење: Ларнака, Кипар 13-20. 10. 2018. Православље (1. октобар 2018).

Pollard, B. (1994). The Challenge of Euthanasia. Crows Nest, NSW: Little Hills Press.

Pollard, B. (2003). Current Euthanasia Law in the Netherlands, New South Wales Right to Life Association. $\odot$ NSW website. 
Taylor, J. (1650). The Rules and Exercises of Holy Living = Taylor, J. (2005). Holy Living and Holy Dying. London: Adamant.

Taylor, J. (1651). The Rules and Exercises of Holy Dying = Taylor, J. (2005). Holy Living and Holy Dying. London: Adamant.

Turner-Stokes, L. J. (2016). A matter of life and death: controversy at the interface between clinical and legal decision-making in prolonged disorders of consciousness. Med Ethics (BMJ Publishing Group), 1-7.

Vlachos, H. (2016). Biology, Bioethics and Bio-theology (Lecture given at the July 18-22 Archdiocesan Clergy Symposium, convened by Metropolitan Joseph and hosted by the Metropolis of the Patriarchate of Antioch. (c) Orthodoxy Cognate Page website). 


\author{
Bogdan Lubardić \\ University of Belgrade, Faculty of Orthodox Theology, Belgrade
}

\title{
Christian understanding of death and the problem of euthanasia: Contribution of the International Commission for Anglican-Orthodox Theological Dialogue (ICAOTD) 2016-2019 - synoptic overview
}

7 he author presents the work of the International Commission for Anglican1 Orthodox Theological Dialogue (ICAOTD) regarding its second, practicalapplicative phase of engagement in the field of Christian anthropology. From the set of five main areas of questions, which are to be thematized in this phase, according to a Christian conceptualization of bioethics, based in agreed principles of Christian anthropology, the Commission first chose two: the question of euthanasia and the question of natural environment. The author offers a synoptic overview of basic results brought out so far, during the 2016-2019 process of discussions about the Christian understanding of death related to the problem of "euthanasia". During plenary discussions about the expert papers presented from both sides (especially in Malta 2017) the Commission also endorsed guiding principles for orientation and evaluation in regard to the complex and sensitive problem induced by the growing acceptability of the practice of euthanasia, and, also in regard to the not entirely predictable consequences of the advances of biotechnology and modern science. Amongst other things, the Commission holds the position that euthanasia, if colloquially interpreted as "assisted suicide", needs to be carefully distinguished from approaches such as assisted dying in general (viz. palliative and hospice care etc), and especially from the ethos of dying well in a re-actualized traditional Christian sense: based on spiritual discernment grounded through a comprehensive as much as holistic ecclesial understanding of dying, death and mortality. In due time, the Commission will endorse an Agreed statement on dying well, viz. euthanasia.

Key words: International Commission for Anglican-Orthodox Theological Dialogue (ICAOTD), Christian anthropology, principles and applications, bioethics, euthanasia, Christian concepts of death and dying.

Датум пријема чланка: 30. 06. 2019.

Датум прихватања чланка за објављивање: 07. 10. 2019. 